\title{
Sibutramine: balanced judgment or prejudice?
}

\section{Sibutramina: julgamento equilibrado ou preconceito?}

Sibutramine has been used worldwide as an anti-obesity agent for nearly 15 years. Some concerns were raised because of its combined peripheral and central sympathomimetic effects and potential long-term impact on cardiovascular risk. ${ }^{1}$

To evaluate the long-term effect of sibutramine on the incidence of cardiovascular outcomes among high-risk subjects, the SCOUT (Sibutramine Cardiovascular Outcome Trial) was designed as a double-blind, placebo-controlled study in which all subjects would be treated with sibutramine before randomization for a lead-in period of six weeks. ${ }^{2}$

The average duration of the SCOUT was 3.4 years. Despite the far lower than expected event rates in each arm of the trial, the risk of a primary outcome event was $16 \%$ higher in the sibutramine group compared with the placebo group $(\mathrm{p}=0.02)$. This increase was due to a higher incidence of nonfatal events (myocardial infarction and stroke), but with no significant difference between the study groups in the incidence of cardiovascular death or death from any cause.

Mean blood pressure levels fell in both groups, but not to such low levels in the sibutramine group as they did in the placebo group after randomization ( 1 to $2 \mathrm{mmHg}$ difference). The mean pulse rate was consistently higher in the sibutramine group throughout the randomization phase. It should be noted, however, that blood pressure levels remained lower after randomization than at baseline, even in those randomized to sibutramine.

Four important characteristics of the SCOUT should be considered when interpreting its results.

First, for ethical reasons, there was no true placebo group because all subjects were treated with sibutramine during the leadin period to allow the exclusion from randomization of subjects with potentially increased sensitivity to sibutramine appearing as substantial increases in blood pressure or heart rate.

Because of the sibutramine treatment during this lead-in period, it seems reasonable to suppose that weight changes seen in the placebo group after randomization resulted from the initial effects of sibutramine rather than from diet and exercise alone in this relatively old patient population where $85 \%$ had long-standing diabetes.

The second important limitation of the trial was its reduced statistical power caused by the overall event rate, which was initially only one-third of the expected based on the results of previous cardiovascular studies. All subgroup analyses were therefore handicapped by the overall low event rate.

The third feature of the SCOUT, also derived from the low event rate, was the need to progressively recruit patients with the highest possible risk in an attempt to reach the required statistical power for the trial. This resulted in a study population remarkably different from the patients using sibutramine in daily life. The vast majority of participants at the entry of the trial would not meet the treatment criteria specified in the sibutramine label. ${ }^{3}$

Fourth, the SCOUT subjects continued to receive therapy for up to six years, regardless of whether they achieved any weight loss or even put on weight. Yet sibutramine has never been recommended as a long-term treatment for patients that did not achieve significant weight loss.

Taking all these characteristics into account, the SCOUT results should not be extrapolated to the general population of obese patients using sibutramine in clinical practice. Cardiovascular risk is known to be far lower in individuals treated according to the label recommendations, not only in what concerns baseline differences in cardiovascular risk, but also because no doctor would continue treatment in those that did not respond with weight loss.

Moreover, there is still much to be learned from the SCOUT results as decisions in the trial were made on the basis of the requirements of regulatory agencies who were not interested in the overall impact of weight loss and were simply concerned with testing safety in patients at far higher risk than those ever exposed to sibutramine. These regulatory agencies then extrapolated the data and conditions to lower-risk patients who do not conform to the SCOUT conditions. Further appropriate analyses are now underway by independent investigators.

When the EMA and the FDA (respectively, the European and North-American regulatory agencies) judged the risk profile of sibutramine based on the SCOUT results, the limitations of the study seemed to be disregarded, as well as the known benefits of weight loss itself in terms of respiratory capacity, mobility, and back pain. Thus, the risk-benefit balance seems to have been biased by the recurrent assumption that too many individuals would be using the medication merely for cosmetic reasons. The efficacy of the drug in terms of weight loss, supported by a previous 
meta-analysis ${ }^{4}$, was deemed insufficient to justify the exposure to potential risks and the recurrent question was "Where was the observed benefit?" The benefits of weight loss were therefore dismissed as a criterion, despite this being the primary requirement for registering a drug for weight loss!

Different criteria seem to apply to different classes of drugs. There is increasing evidence indicating the association of nonsteroidal anti-inflammatory agents with increased cardiovascular risk, but for other reasons the risk-benefit profile seems to be still deemed favorable. ${ }^{5,6}$ Drugs used for diabetes are also acceptable provided the cardiovascular risk is increased by less than 33\%; i.e., twice the level in the SCOUT trial with its very high-risk patients not conforming to the label requirements. This raises the question as to whether the approaches are comparable and based on the best scientific evidence available or are contaminated by prejudice.
Given the widespread crude interpretation of the significance and causes of obesity, this is certainly a matter for open discussion and careful consideration.

There are no new anti-obesity agents currently available to replace sibutramine. Therefore, if other regulatory agencies decide for the withdrawal of sibutramine, tens of thousands of patients are likely to regain weight and to have their absolute cardiovascular risk significantly incremented as their weight increases.

Walmir Coutinho, M.D., D.Sc.

Catholic University of Rio de Janeiro and State Institute of Diabetes and Endocrinology of Rio de Janeiro

W. Philip T. James, M.D., D.Sc.

London School of Hygiene and Tropical Medicine, London

\section{Disclosures}

\begin{tabular}{|c|c|c|c|c|c|c|c|}
\hline $\begin{array}{l}\text { Writing } \\
\text { group } \\
\text { member }\end{array}$ & Employment & $\begin{array}{c}\text { Research } \\
\text { grant }^{1}\end{array}$ & $\begin{array}{l}\text { Other research } \\
\text { grant or medical } \\
\text { continuous } \\
\text { education }\end{array}$ & $\begin{array}{l}\text { Speaker's } \\
\text { honoraria }\end{array}$ & $\begin{array}{l}\text { Ownership } \\
\text { interest }\end{array}$ & $\begin{array}{l}\text { Consultant/ } \\
\text { Advisory } \\
\text { board }\end{array}$ & Other $^{3}$ \\
\hline Coutinho W & $\begin{array}{c}\text { Catholic } \\
\text { University of } \\
\text { Rio de Janeiro } \\
\text { and State } \\
\text { Institute of } \\
\text { Diabetes and } \\
\text { Endocrinology } \\
\text { of Rio de } \\
\text { Janeiro }\end{array}$ & $\begin{array}{c}\text { Sanofi- } \\
\text { Aventis } \\
\text { Abbott } \\
\text { Jansen }\end{array}$ & - & $\begin{array}{l}\text { Novo } \\
\text { Nordisk } \\
\text { Abbott } \\
\text { Nutrition }\end{array}$ & - & $\begin{array}{c}\text { Germed } \\
\text { Pharma } \\
\text { Ache } \\
\text { Glaxo } \\
\text { Smithkline } \\
\text { Novo Nordisk } \\
\text { Takeda } \\
\text { Vivus } \\
\text { Weight } \\
\text { Watchers } \\
\text { International }\end{array}$ & $\begin{array}{c}\text { Member of } \\
\text { SCOUT } \\
\text { Executive } \\
\text { ISteering } \\
\text { Committee } \\
\text { (Abbott) }\end{array}$ \\
\hline James WP & $\begin{array}{l}\text { London } \\
\text { School of } \\
\text { Hygiene and } \\
\text { Tropical } \\
\text { Medicine, } \\
\text { London, UK }\end{array}$ & - & - & $\begin{array}{c}- \\
\text { Universities*/ } \\
\text { NGOs*I } \\
\text { Investment } \\
\text { companies*/ } \\
\text { EU } \\
\text { Parliament* }\end{array}$ & - & - & $\begin{array}{l}\text { Chair of } \\
\text { SCOUT } \\
\text { Executive } \\
\text { Steering } \\
\text { Committee } \\
\text { (Abbott) }^{\star \star}\end{array}$ \\
\hline $\begin{array}{l}{ }^{*} \text { Modest } \\
{ }^{* *} \text { Significant }\end{array}$ & & & & & & & \\
\hline
\end{tabular}

References

1. Heusser K, Tank J, Diedrich A, Engeli S, Klaua S, Krüger N, Strauss A, Stoffels $\mathrm{G}$, Luft FC, Jordan J. Influence of sibutramine treatment on sympathetic vasomotor tone in obese subjects. Clin Pharmacol Ther. 2006;79(5):500-8.

2. James WP, Caterson ID, Coutinho W, Finer N, Van Gaal LF, Maggioni AP, Torp-Pedersen C, Sharma AM, Shepherd GM, Rode RA, Renz CL; SCOUT Investigators. Effect of sibutramine on cardiovascular outcomes in overweight and obese subjects. N Engl J Med. 2010;363(10):905-17.

3. Meridia. North Chicago, IL: Abbott Laboratories (package insert). [cited 2011 May 22] Available from: http://www.fda.gov/downloads/Drugs/DrugSafety/ PublicHealthAdvisories/UCM130745.pdf.

4. Rucker D,Padwal R,Li SK,Curioni C,Lau DC.Long term pharmacotherapy for obesity and overweight: updated meta-analysis. BMJ. 2007;335(7631):1194-1199.

5. García Rodríguez LA, González-Pérez A, Bueno H, Hwa J. NSAID use selectively increases the risk of non-fatal myocardial infarction: a systematic review of randomised trials and observational studies. PLoS One. 2011;6(2):e16780.
6. Bavry AA, Khaliq A, Gong Y, Handberg EM, Cooper-Dehoff RM, Pepine CJ. Harmful Effects of Nonsteroidal Anti-inflammatory Drugs among Patients with Hypertension and Coronary Artery Disease. Am J Med. In press 2011. 